Hadler, N.M., Gerwin, R.D., Franklin, M.M., Whitaker, J.N., BAKER, M. \& DECKER, J.L. (1973) The fourth component of complement in the cerebrospinal fluid in systemic lupus erythematosus. Arthritis and Rheumatism, 16, 507.

Harbeck, R.J., Hoffman, A.A., Carr, R.I. \& Baradana, E.J. (1973) DNA antibodies and DNA: anti-DNA complexes in cerebral spinal fluid of patients with systemic lupus erythematosus. Arthritis and Rheumatism, 16, 552.

KeEFFe, E.B., BaRAdana, E.J., Jr \& HaRbeck, R.J. (1974) Lupus meningitis. Annals of Internal Medicine, 80, 58.

Koffler, D., Agnello, V., Thoburn, R. \& Kunkel, H.G. (1971) Systemic lupus erythematosus prototype of immune complex nephritis in man. Journal of Experimental Medicine, 134, 169.

Levin, A.S., Fudenberg, H.H., Petz, L.D. \& Sharp, G.C. (1972) IgG levels in cerebrospinal fluid of patients with central nervous system manifestations of systemic lupus erythematosus. Clinical Immunology and Immunopathology, $1,1$.
Levo, Y., Pick, A.I., Nir, M.A., Weiss, C. \& Feuerman, E.J. (1973) Correlation between immunological parameters and cutaneous manifestations of systemic lupus erythematosus. Dermatologia. 147, 316.

OYAMA, J.H. (1971) Diagnosis and treatment of lupus nephritis. Medical Clinics of North America, 55, 71.

Petz, L.D., SharP, G.C., CoOper, N.R. \& Irvin, W.S. (1971) Serum and cerebral spinal complement and serum autoantibodies in systemic lupus erythematosus. Medicine, 50, 259.

Pick, A.I., Levo, Y. \& Weiss, C. (1974) The value of antiDNA antibody titers in the early diagnosis, treatment and followup of systemic lupus erythematosus. Israel Journal of Medical Sciences, 10, 725.

Pincus, T., Hughes, G.R.V., Pincus, D., Tina, L.V. \& Bellanti, J.A. (1971) Antibodies to DNA in childhood systemic lupus erythematosus. Journal of Pediatrics, 78, 981.

Postgraduate Medical Journal (December 1976) 52, 798-800.

\title{
Alpha-chain disease in an Englishman
}

\author{
S. W. S. WANG* \\ M.B., Ch.B., M.R.C.P. \\ Liverpool Royal Infirmary
}

\begin{abstract}
Summary
Eighty cases of the gastro-intestinal form of alphachain disease had been reported up to the time of writing this communication (September 1975). All patients were non-Caucasians. This report presents a case of this disorder in an Englishman who became ill whilst working in the tropics. His clinical features and response to therapy were entirely in line with the other cases so far reported.
\end{abstract}

\section{Introduction}

The first case of alpha-chain disease was described in 1968 (Ramboud et al., 1968; Seligman et al., 1968). By July 1975 a total of eighty cases had been reported (Doe et al., 1972; Manousos et al., 1974; Seligmann, 1975a, b).

Abdominal pain, weight-loss, steatorrhoea and marked finger clubbing are the main features (Ramboud and Matuchansky, 1973; Seligmann, 1975c).

\footnotetext{
* Present address: Department of Cardiology, Manchester Royal Infirmary, Oxford Road, Manchester M13 9WL.
}

A case is now reported where the presenting features were vomiting due to upper intestinal obstruction, weight-loss, steatorrhoea, anaemia and occult gastro-intestinal tract bleeding, and finally response to treatment with cyclophosphamide, prednisolone and tetracycline was achieved.

\section{Case history}

The patient, an Englishman, was first seen in 1966 (when he was 31 years old) at the School of Tropical Medicine, Liverpool, with a 7-month history of vomiting and diarrhoea, which had developed while he was working in Cameroon, West Africa. He had earlier worked for 3 years in Mauritius. Apart from having had 'stomach trouble' as an adolescent, there had been no significant illnesses in the past.

In December 1965 he developed vomiting and diarrhoea which lasted for about 1 week and then improved, but there were several recurrences in the course of the next few months. In July 1966 he developed severe and persistent vomiting and diarrhoea. He was sent back to Britain for medical 


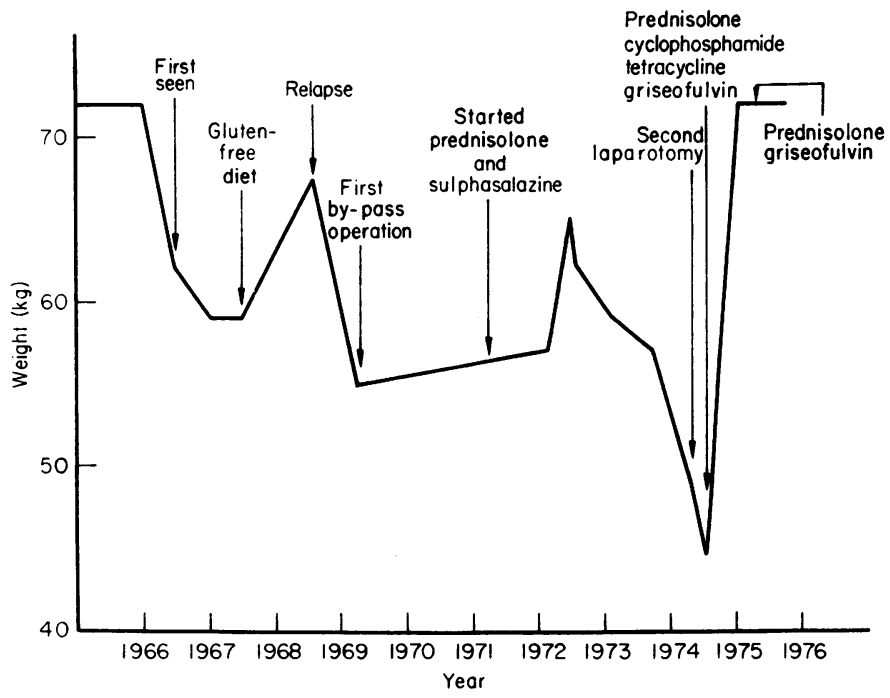

FIG. 1. Weight chart (1966-1975).

attention; he had lost $9.5 \mathrm{~kg}$ in weight in 7 months and now weighed only $62.5 \mathrm{~kg}$.

When seen at the School of Tropical Medicine, no evidence was found to suggest that he might have contracted a tropical disease. However, steatorrhoea was discovered. He received a diet rich in protein and low in fat content. At review in January 1967, steatorrhoea had persisted and he had lost more weight (Fig. 1). There was no anaemia or cedema; blood urea and serum electrolytes, calcium, phosphate and alkaline phosphatase were all normal. The serum albumin was $2.85 \mathrm{~g} / 100 \mathrm{ml}$ and globulin 2.34 $\mathrm{g} / 100 \mathrm{ml}$.

Jejunal biopsy was carried out using a Crosby capsule. Histology showed 'a mixture of partial and sub-total villous atrophy with marked infiltration by eosinophils, lymphocytes and plasma cells'. He was treated with a gluten-free diet and a temporary improvement was noted. Later, pancreatin, vitamin $\mathrm{D}$ and oral calcium therapy were added.

By February 1968 he had gained $7 \mathrm{~kg}$ in weight and the vomiting and diarrhoea had ceased. In November of the same year, however, his condition relapsed, with return of vomiting and diarrhoea. He was admitted to Liverpool Royal Infirmary where a barium meal revealed obstruction at the level of the distal duodenum and proximal jejunum. A laparotomy was carried out in January 1969. The whole of the small intestine was found to be oedematous. There was no enlargement of lymph nodes, and no hepato-splenomegaly. A posterior gastro-jejunostomy and a duodeno-jefunostomy were performed to relieve obstruction. Specimens of duodenum and lymph node were sent for histology. The duodenal mucosa showed marked infiltration with eosinophils, lymphocytes and plasma cells. The lymph node was reported as normal.

His condition fluctuated after the by-pass operation. In March 1970, he was found for the first time to be anaemic. The haemoglobin was $10.5 \mathrm{~g} / 100 \mathrm{ml}$, the anaemia being microcytic and hypochromic. Repeated tests for occult blood in faeces were positive. He received oral iron therapy and vitamin $B_{12}$ injection. In April 1971 vomiting and diarrhoea recurred and he was again admitted to hospital. He was wasted and pale. The haemoglobin was now $8.9 \mathrm{~g} / 100 \mathrm{ml}$. The serum calcium was $9.3 \mathrm{~g} / 100 \mathrm{ml}$, and both phosphate and alkaline phosphatase were normal. The serum albumin was $2.9 \mathrm{~g} / 100 \mathrm{ml}$ and globulin $2.8 \mathrm{~g} / 100 \mathrm{ml}$. A barium meal suggested obstruction at the level of the proximal jejunum.

The possibility of Crohn's disease was considered and he was treated with prednisolone and sulphasalazine, and was transfused. During the next 3 years his condition remained static.

In April 1974 he was re-admitted to hospital owing to further deterioration. He had now lost 21 $\mathrm{kg}$ in weight altogether since 1966, and weighed only $49 \mathrm{~kg}$. He was emaciated and pale. There was, however, no clubbing, oedema, or lymphadenopathy. The liver and spleen were not enlarged.

There was still evidence of blood-loss from the gastrointestinal tract. The haemoglobin was 7.4 $\mathrm{g} / 100 \mathrm{ml}$. The serum iron was $30 \mu \mathrm{g} / 100 \mathrm{ml}$, and the total iron-binding capacity was only $7 \%$ saturated. The serum albumin was $2.3 \mathrm{~g} / 100 \mathrm{ml}$ and globulin $1.8 \mathrm{~g} / 100 \mathrm{ml}$. A further barium meal showed obstruction at the previously constructed gastroenterostomy.

A further laparotomy was performed to refashion 
the by-pass. At operation, oedematous and atonic gut was observed. The post-operative course was stormy, with chest and wound infections occurring.

At this stage, alpha-chain disease was suspected. An operative specimen of jejunum was studied in the University sub-Department of Immunology (Director, Dr J. Bradley). The jejunal mucosa was infiltrated with lymphocytes and plasma cells at the villi and their bases. The cells were considered to be producing alpha-chain since they fluoresced with anti-alpha-chain antibodies. Unfortunately, owing to the shortage of anti-light-chain anti-sera, a confirmatory immuno-electrophoretic test of the patient's serum for free alpha-chain (which is the heavy chain of $\operatorname{IgA}$ ) was not carried out. Serum immunoglobulin studies showed: IgG, $680 \mathrm{mg} / 100$ $\mathrm{ml}$ (normal, $220-1240 \mathrm{mg} / 100 \mathrm{ml}$ ); IgA, $190 / 100 \mathrm{ml}$ (normal, 70-280 mg/100 ml); IgM $280 \mathrm{mg} / 100 \mathrm{ml}$ (normal, 35-120 mg/100 ml).

The patient was treated with cyclophosphamide $100 \mathrm{mg}$ daily, prednisolone $5 \mathrm{mg}$ t.d.s. and tetracycline $500 \mathrm{mg}$ q.d.s. Later, because of a fungal infection of the nails, he was given griseofulvin. Two months later, the vomiting and diarrhoea had disappeared and he had gained $7 \mathrm{~kg}$ in weight. In December 1974, his weight was $66 \cdot 22 \mathrm{~kg}$. The cyclophosphamide therapy was discontinued and the prednisolone dosage reduced to $5 \mathrm{mg}$ b.d.

When last seen, in September 1975, the patient weighed $70.76 \mathrm{~kg}$ and had recovered his good health. Haemoglobin, plasma urea and electrolytes were all normal.

\section{Discussion}

Alpha-chain disease was initially regarded as geographically region-specific, and hence the term 'Mediterranean' was applied to it. Later, it was regarded as ethnic-related (Ramot and Hulu, 1975; Doe, 1975).

The present case is believed to be the first example of the intestinal form of this condition to be reported from a Caucasian.

There is a remarkable similarity between patients with this disease, and in the present case, the clinical picture, the course of the illness and the response to therapy were similar to those in the other reported cases. Unfortunately, the full confirmatory tests were not performed but it would be reasonable to make the diagnosis of alpha-chain disease on the basis of the features described.

It is interesting to note that the patient apparently responded initially to a gluten-free diet. It is hard to say whether such a response was merely a chance finding or whether he did initially have coeliac disease and later developed alpha-chain disease. Later, the apparent response to a regimen of prednisolone and sulphasalazine might well have been due to a partial response of the alpha-chain disease to the systemic steroid.

\section{Acknowledgment}

The author wishes to thank Dr D. R. Seaton, of the School of Tropical Medicine, Liverpool, and Mr D. Annis and Professor D. A. Price Evans of the Liverpool Royal Infirmary for permission to publish the details of this patient.

\section{Addendum}

Since the submission of this paper, another case of alphachain disease has been reported (Shulman, Lai York and Grieve, 1975), bringing the total to eighty-two. But the present report remains the first from a Caucasian patient.

\section{References}

Doe, W.E., Henry, K., Hobbs, J.R., Avery Jones, F., Dent C.E. \& Bоотн, C.C. (1972) Five cases of alpha chain disease. Gut, 13, 947.

DoE, W.F. (1975) Alpha chain disease: clinicopathological features and relationship to so-called Mediterranean lymphoma. British Journal of Cancer, 31 (Suppl. 2), 350.

Manousos, O.N., Economidou, J.C., Georgiadou, D.E. Pratsika-Ougourloglou, K.G., Hadziyannis, S.J. Merikas, G.E., Henry, K. \& DoE, W.F. (1974) Alpha chain disease with clinical, immunological and histological recovery. British Medical Journal, 2, 409.

Ramboud, J.C., Boguel, C., Prost, A., Bernier, J.J., Le Quintrec, Y., Lambling, A., Danon, F., Hurez, D. \& SeligmanN, M. (1968) Clinico-pathological study of a patient with "Mediterranean" type of abdominal lymphoma and a new type of IgA abnormality (alpha chain disease). Digestion, 1, 321.

Ramboud, J.C. \& Matuchansky, C. (1973) Alpha-chain disease: pathogenesis and relation to Mediterranean lymphoma. Lancet, i, 1430.

Ramot, B. \& Hulu, N. (1975) Primary intestinal lymphoma and its relation to alpha heavy chain disease. British Journal of Cancer, 31 (Suppl. 2), 343.

Seligmann, M., Danon, F., Hurez, D., Mihaesco, E. \& Preud'homme, J.-L. (1968) Alpha chain disease: a new immunoglobulin abnormality. Science, 162, 1396.

Seligmann, M. (1975a) Immunological, clinical and pathological features of alpha-chain disease. Archives of Internal Medicine, 135, 78.

Seligmann, M. (1975b) Alpha heavy chain disease. Blut, 31, 1.

Seligmann, M. (1975c) Alpha chain disease: immunoglobulin abnormalities, pathogenesis and current concepts. British Journal of Cancer, 31 (Suppl. 2), 356.

Shulman, G., LaI York, E. \& GrieVe, S. (1975) Alpha-chain disease in a non-mediterranean climate. South African Medical Journal, 49, 2183. 